\title{
常磐磐城砿業所の全充㙗による作業環境の改善 と総合合理化
}

（第43回 渡辺賞牌受賞）

岡 部 元 治 ${ }^{1}$

\section{1. まえがき}

炭鈗における払跡の全充填はその目的とするところは 主として鈗害問題の緩和であり，乙たがつて同一炭鉣で も，その問題の発生する抢それのある区域のみを対象と したいわば局部的なものである。しかるに当所の全充填 の目的は, 従来の総ばらし方式では払跡から発生する熱 気によつて異常なまでに温度が上杲し媣部採掘は不可能 に陥るのでこの熱気を遮断するためにとられた手段で ある。

しかも全区域が温泉地带のため全払について充填する ことが必要で, 現在 4 払で $80,000 \mathrm{~m}^{3} /$ 月におよぶ膨大な 充填を行なつている。このような大量の充填量のために 他の炭鉣における充填材のように20 $80 \mathrm{~mm}$ といら適材 みを使用することが許されずー $20 \mathrm{~mm}$ もずて使用して のいる点に特色がある。

この充填の結果, 熱気は完全に遮断され大幅な温度低 下を来たすとともに従来問題であつた自然発火，重圧， 出水等の抑制にも効果が顕著で, 今日にあつては必要欠 くべからざる多目的な充塡となつている。

この充顚によつて当所の坑内は様相を一変するまでに 若返り, これを足場として切羽の重装備化, 集約をなし 総合的な合理化をなし遂げたのである。

以下その経過について大略述べることとする。

\section{2. 自然条件亡従来の対策}

\section{$2 \cdot 1$ 作業環境とその対策}

採掘区域が温泉地帯と合致するため地温増加率は高く

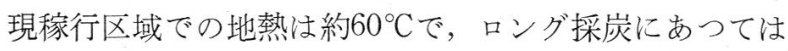
第 1 図に示すごとく払跡の熱気によって切羽上部は急激 に温度上昇し, $40^{\circ} \mathrm{C}$ 超え保坑はもちろん, 㳠迴すら困 難な状態であつた。

この環境を改善するために風量増加を目的とする立坑 の開さく(過去10年間に12本), 扇風機の増強 $(1,600 \mathrm{~kW})$ あるいは中割坑道を設け通気短絡をして肩坑道の温度を 下げるとともに払を 200 300m で切換えるとか，ビニ

* 昭啝 44 年 4 月 14 日受理 昭和 44 年 4 月 2 日, 本会春李大会飞て発表

1. 正会員 常磐孷砸株式会社取締役 督城矿業所砸務部長
一ル幕を設け熱気の流入を防止する等の方法索講じてき たが，いずれも抜本的な解決には至らず，もはや温度的 にはその限界に来ていた。

\section{$2 \cdot 2$ 払の重圧とその対策}

当所の上盤憬い砂岩で, 下盤は軟弱な頁岩のため払 における地圧コントロールがきわめて困難で, 払進行と ともにしばしば重圧があり，切羽を喂失することがあつ た。第 2 図はその一例で，片盤長 $406 \mathrm{~m}$ を採掘する間に 実に15回の重圧があり，そのつど天盤沈下，崩落，鉄柱 カッペの破損在来たし，とくに始発部より $236 \mathrm{~m}$ の地点 で遭遇した重圧では $67 \mathrm{~m}$ にわたつて切羽が完全に埋没 し，正常な切羽に戻すために約 1 力月費やした。

この重圧対策として払跡の吊天盤に向つて穿孔発破を して強制的に跡ばれを助長させるとか，複列千鳥方式を とり支柱密度を2 倍にする等の方策を講じたが，これと て完全な対策には至らず依然として重压は発生し，さら には支保作業が多くなり能率を低下させた。

\section{$2 \cdot 3$ 自然発火とその対策}

残柱または発破による飛散炭が自然発火を起こし，熱 気の助長あるいは最悪の場合は払を撤退することが時々 生じていた。この対策として当社が納炭する常磐共同火 力より発生するフライアッシュを漏風防止のための深側

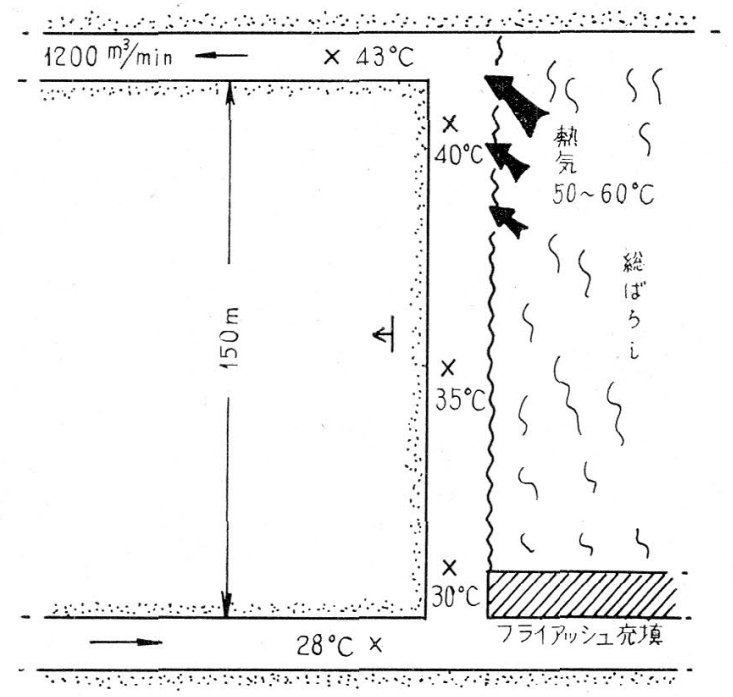

第 1 図 熱気による払温度上早の実例

$394\langle 8\rangle$ 


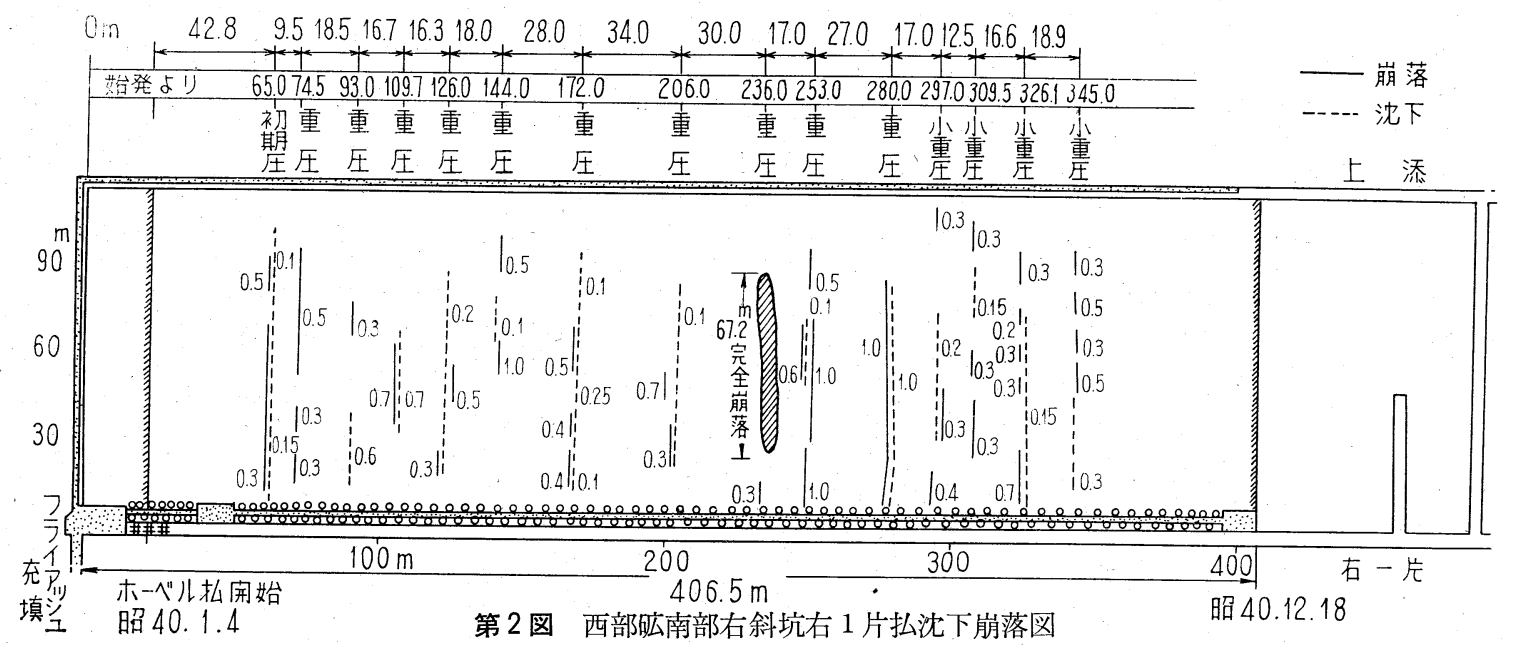

の帯状充填, 残柱炭の被覆, 不要坑道の遮断等に使用し, 大いにその効果を上げたが，払跡残炭の酸化作用による 熱気を防止するまでには至らず完全に自然発火が絶たれ た状態ではなかつた。

\section{$2 \cdot 4$ 硬炭とその対策}

当所の石炭は非常に硬く（F D : 10〜20）ホーベル， ドラムカッタに先行してゆるめ発破をしなければなら ず，これらの機械はむしろ積込機として使用されていた に過ぎない。このため発破によるトラブルすなわち飛散 炭の増加, 機器の故障, 実働時間の減少等を余儀なくさ れていた。

\section{$2 \cdot 5$ 温泉湧出とその対策}

下盤に高い圧力を有する温泉を包蔵しているため常に 出水の危険にさらされていた。この対策として下盤への 垂直ボーリングによつて強制的に抜水し，水位を低下さ せることに成功し, 現在約 $120 \mathrm{~m}^{3} / \mathrm{min}$ の温泉系排水量 中 $65 \%$ この強制抜水量である。しかし採掘の進展に水 位の低下が必ずしも追随できず完全に出水の危険から解 放された状態ではなかつた。

\section{3. 全充填による作業環境の改善}

上述のような苛酷な自然条件に対して, 諸施策を行な つてきたがいずれも抜本的な解決には至らず，このまま 推移すれば当所の採掘命数はもはや時間の問題となつ た。そこで当面の最大問題である熱気の遮断を目的とす る払跡の全充塡を実施することにした。もちろん温度問 題ばかりでなく自然発火の防止, 出水の予防, 払重圧の 根絶, 災害の減少, 鉱害の予防, 実収炭量の増加から払 出炭量の増大，採掘場の集約など，合理化につながるき わめて多岐にわたる効果を期待し 39 年 7 月より基礎的調 查に大り，ついで 41 年 5 月より西部矿で 1 払の充填切羽 の操業に踏み切つた。その結果多目的として挙げた効果 がきわめて顕著であることが把握できたので，41年11月 に全払の充填化工事に着手し 42 年11月より 4 払の操業に 入つたのである。

\section{$3 \cdot 1$ 基礎的調查および吹付試験}

充塡能率, 空気消費量, 充塡機および充填パイプの閉 塞, その他のトラブルは充塡材料に大きく左右されるの で，あらゆる充填材料について粒度分布，比重，水分， 粘着力等について調査するとともに自然発火の見地から 充填材の発熱性, あるいは出水予防の面から充填材の圧 縮性等について基礎的実験を行なつた。その結果つぎの ことが判明した。

i ）粘着力は微細なものが混入するほど大きくなる。 充填材の粒度分布をみると第 1 表に示すように，ズリ 山の $65 \%$ は $10 \mathrm{~mm}$ 以下である。一方，第 2 表にみるよう に日産もののみの供給量では $60,000 \mathrm{t} /$ 月 の出炭分しか なく，ズリ山より約 $30,000 \mathrm{~m}^{3} /$ 月の搬入が必要である。

また $10 \mathrm{~mm}$ 以上のみを使用すればー $10 \mathrm{~mm}$ については 別に搭場を設けねばならず，さらにズリ山の寿命も $1 \frac{1}{3}$ 以 下となる。このことから-10mm についてもぜひ使用す

第 1 表 充塡材の粒度分布

\begin{tabular}{|c|c|c|c|c|c|c|}
\hline \multirow{2}{*}{$\frac{\text { 粒 }}{(\mathrm{mm})}$} & 東 & 部 & 磄 & 西 & 部 & 磄 \\
\hline & 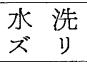 & $\begin{array}{cc}\text { 掘 } & \text { 進 } \\
\text { ズ } & リ\end{array}$ & $\begin{array}{l}\text { ズリ山 } \\
\text { ズリ }\end{array}$ & $\begin{array}{ll}\text { 水 } & \text { 洗 } \\
\text { ズ } & \text { リ }\end{array}$ & $\begin{array}{ll}\text { 掘 } & \text { 進 } \\
\text { ズ } & \text { リ } \\
\end{array}$ & $\begin{array}{l}\text { ズリ山 } \\
\text { ズ リ }\end{array}$ \\
\hline $\begin{array}{r}+80 \\
80 \sim 10 \\
-10\end{array}$ & $\begin{array}{c}0 \\
94.1 \\
15.9\end{array}$ & $\begin{array}{l}35.6 \\
55.73 \\
8.67\end{array}$ & $\begin{array}{c}0 \\
34.25 \\
65.76\end{array}$ & $\begin{array}{r}5.23 \\
80.44 \\
14.33\end{array}$ & $\begin{array}{l}39.07 \\
32.54 \\
28.49\end{array}$ & $\begin{array}{c}0 \\
34.31 \\
65.69\end{array}$ \\
\hline
\end{tabular}

第 2 表＼cjkstart払出炭計画と全充㙗に要するズリ量

\begin{tabular}{|c|c|c|c|c|c|}
\hline & 東部 硫 & 西 部 砿 & 計 \\
\hline \multicolumn{3}{|c|}{$\begin{array}{l}\text { 全 出炭 } t / \text { 月 } \\
\text { 崖出 } \\
\text { 必要ズリ量 } \mathrm{m}^{3} / \text { 月 }\end{array}$} & $\begin{array}{l}60,000 \\
50,000 \\
35,000\end{array}$ & & $\begin{array}{r}150,000 \\
125,000 \\
87,500\end{array}$ \\
\hline $\begin{array}{l}\text { 日ズ } \\
\text { 産リ } \\
\text { b } \\
\text { の量 }\end{array}$ & $\begin{array}{l}\text { 水洗ズリ } \\
\text { 掘進ズリ } \\
\text { リンカ } \\
\text { 計 }\end{array}$ & $\begin{array}{l}\text { " } \\
" \\
"\end{array}$ & $\begin{array}{r}10,800 \\
7,300 \\
3,500 \\
21,600\end{array}$ & $\begin{array}{r}19,000 \\
14,000 \\
3,500 \\
36,500\end{array}$ & $\begin{array}{r}29,800 \\
21,300 \\
7,000 \\
58,100\end{array}$ \\
\hline \multicolumn{3}{|c|}{$\begin{array}{l}\text { ズリ山より搬入 } \\
\text { 必要ズリ量 }\end{array}$} & 13,400 & 16,000 & 29,400 \\
\hline $\begin{array}{l}\text { ズ } \\
\text { リ } \\
\text { 山 } \\
\text { 量 }\end{array}$ & $\begin{array}{l}\text { 堆 積 量 } \\
\text { 地 山 量 } \\
\text { 計 } \\
\text { 寿 命.年 }\end{array}$ & & $\begin{array}{r}7,452,000 \\
166,000 \\
7,618,000 \\
48\end{array}$ & $\begin{array}{r}4,404,000 \\
7,474,000 \\
11,878,000 \\
62\end{array}$ & $\begin{array}{r}11,856,000 \\
7,640,000 \\
19,496,000 \\
55\end{array}$ \\
\hline
\end{tabular}


第 3 表 充 填 材 料 吹 付 試 験

\begin{tabular}{|c|c|c|c|c|c|c|c|c|c|c|}
\hline 陚験充媜材料 項 目 & $\begin{array}{c}\text { 混 } \\
\% \\
\%\end{array}$ & $\begin{array}{l}\begin{array}{c}\text { Iヤー量 } \\
\mathrm{m}^{3} / \mathrm{h}\end{array} \\
\end{array}$ & $\begin{array}{l}\text { 正次 压 } \\
\mathrm{kg} / \mathrm{cm}^{2}\end{array}$ & $\begin{array}{l}\text { 二 次 圧 } \\
\mathrm{kg} / \mathrm{cm}^{2}\end{array}$ & 湿 ${ }^{\text {分 }}$ & $\begin{array}{c}\text { 添加水量 } \\
\mathrm{t} / \mathrm{h}\end{array}$ & 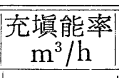 & サ比重 & $\begin{array}{c}\text { 添加水量 } \\
\%\end{array}$ & $\begin{array}{l}\text { 空気消費量 } \\
\mathrm{m}^{3} / \mathrm{m}^{3}\end{array}$ \\
\hline $\begin{array}{ll}\text { 水 洗 } & \text { ズ } \\
\text { 掘 } & \text { 進 } \\
\text { ズ }\end{array}$ & $\begin{array}{l}100 \\
100\end{array}$ & $\begin{array}{l}6,500 \\
6,900\end{array}$ & $\begin{array}{l}3.2 \sim 4.0 \\
3.2 \sim 3.5\end{array}$ & $\begin{array}{l}2.0 \\
2.0\end{array}$ & $\left|\begin{array}{c}10 \sim 12 \\
3.0 \sim 4.5\end{array}\right|$ & $\begin{array}{l}2.5 \\
2.7\end{array}$ & $\begin{array}{l}65 \sim 70 \\
60 \sim 65\end{array} \mid$ & $\begin{array}{l}1.40 \\
2.4\end{array}$ & $\begin{array}{l}2.7 \\
1.7\end{array}$ & $\begin{array}{l}110 \\
115\end{array}$ \\
\hline $\begin{array}{l}\text { 混 } \\
\text { (水洗ズリ合掘進ズリークリンカ) }\end{array}$ & $21: 27: 52$ & 8,000 & $4.5 \sim 5.0$ & $3.2 \sim 2.5$ & $11 \sim 15$ & $1.7 \sim 2.5$ & $85 \sim 100$ & 1.39 & $0.8 \sim 1.8$ & $80 \sim 100$ \\
\hline 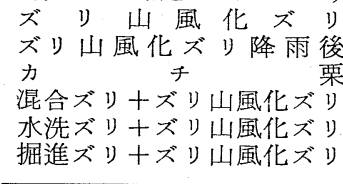 & $\begin{array}{c}100 \\
100 \\
100 \\
50: 50 \\
70: 30 \\
70: 30\end{array}$ & $\begin{array}{l}5,005 \\
5,566 \\
5,448 \\
5,740 \\
6,145 \\
5,514\end{array}$ & $\begin{array}{c}3.2 \\
3.2 \\
3.0 \\
3.2 \\
3.4 \sim 3.6 \\
2.5 \sim 3.7\end{array}$ & $\begin{array}{c}2.4 \\
2.0 \sim 2.1 \\
2.4 \\
2.1 \\
2.0 \sim 2.4 \\
1.5 \sim 3.2\end{array}$ & $\begin{array}{c}13 \sim 15 \\
15.6 \\
\overline{9.3} \\
10 \sim 13 \\
6.0\end{array}$ & $\begin{array}{l}4.0 \\
1.79 \\
5.4 \\
3.5 \\
3.0 \\
3.5\end{array}$ & $\begin{array}{c}44.6 \\
22.3 \\
35 \\
60 \sim 70 \\
50 \sim 65 \\
50 \sim 60\end{array}$ & $\begin{array}{l}1.30 \\
1.41 \\
1.17 \\
1.45 \\
1.26 \\
2.0\end{array}$ & $\begin{array}{r}6.9 \\
10.0 \\
13.0 \\
1.7 \\
5.3 \\
3.5\end{array}$ & $\begin{array}{r}112 \\
250 \\
155 \\
95 \\
122 \\
110\end{array}$ \\
\hline 備 & $\begin{array}{l}\text { 充填 } \\
\text { 充填 }\end{array}$ & & & & & & & & & \\
\hline
\end{tabular}

ることが必要となる。しかるに吹付試験の結果は第 3 表 に示すように混合の如何によつては充分使用可能である ことが判明した。

ii）各種充填材について恒温槽における発熱試験の結 果，自然発火のおそれのないことが確認された。

iii）充娯後 1 力月を経過すれば充填材は $10 \mathrm{~kg} / \mathrm{cm}^{2}$ の 圧縮強度を示し，これは $100 \mathrm{t} / \mathrm{m}^{2}$ の支持力を有すること になるので出水, 重圧の面で良い影響があるものと推定 された。

\section{$3 \cdot 21$ 払充填とその効果}

充塡材料に一応解決のメドがついたので 41 年 5 月より 西部砿に 1 払の充继切羽を第 4 表に示すような設備投資 を以つて設定した。

充填材の採取運搬系統は第 3 図に示すようで, 選 炭 場より出た水洗ズリと火力発電所より搬入されたクリン カは坑口の $100 \mathrm{~m}^{3}$ ポケットに運搬され, これより $2 \mathrm{~m}^{3}$ 炭車に積み込まれ西部斜坑， $-600 \mathrm{~m}$ 電車坑を経て 400
第 4 表 西部矿 1 払充填設備投資経費

\begin{tabular}{|c|c|c|c|c|}
\hline \multirow{2}{*}{\multicolumn{2}{|c|}{ 区 }} & \multicolumn{2}{|c|}{ 西 } & \multirow[b]{2}{*}{ 要 } \\
\hline & & $\begin{array}{l}\text { 金 額 } \\
\text { (千円) }\end{array}$ & 摘 & \\
\hline \multicolumn{2}{|c|}{$\begin{array}{l}\text { 坑 } \\
\text { コンプレッサ建物等 }\end{array}$} & $\begin{array}{r}34,464 \\
2,985\end{array}$ & \multicolumn{2}{|c|}{$\begin{array}{l}385.2 \mathrm{~m} \\
\text { 建家, バック }\end{array}$} \\
\hline 械 & 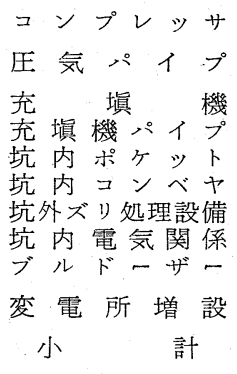 & $\begin{array}{r}33,083 \\
10,995 \\
22,102 \\
9,251 \\
5,570 \\
21,956 \\
15,111 \\
2,150 \\
2,260 \\
4,970 \\
127,448\end{array}$ & \multicolumn{2}{|c|}{ 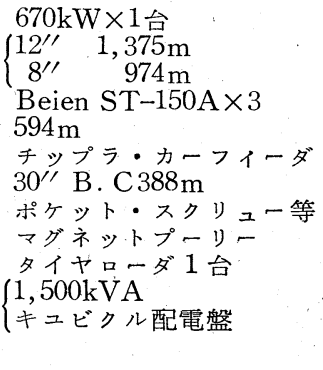 } \\
\hline & 計 : & 164,897 & & \\
\hline
\end{tabular}

$\mathrm{m}^{3}$ 坑内ポケットに投入される。ついで電磁フィーダで 引き出されベルトを経て，払肩坑道に設置されている充

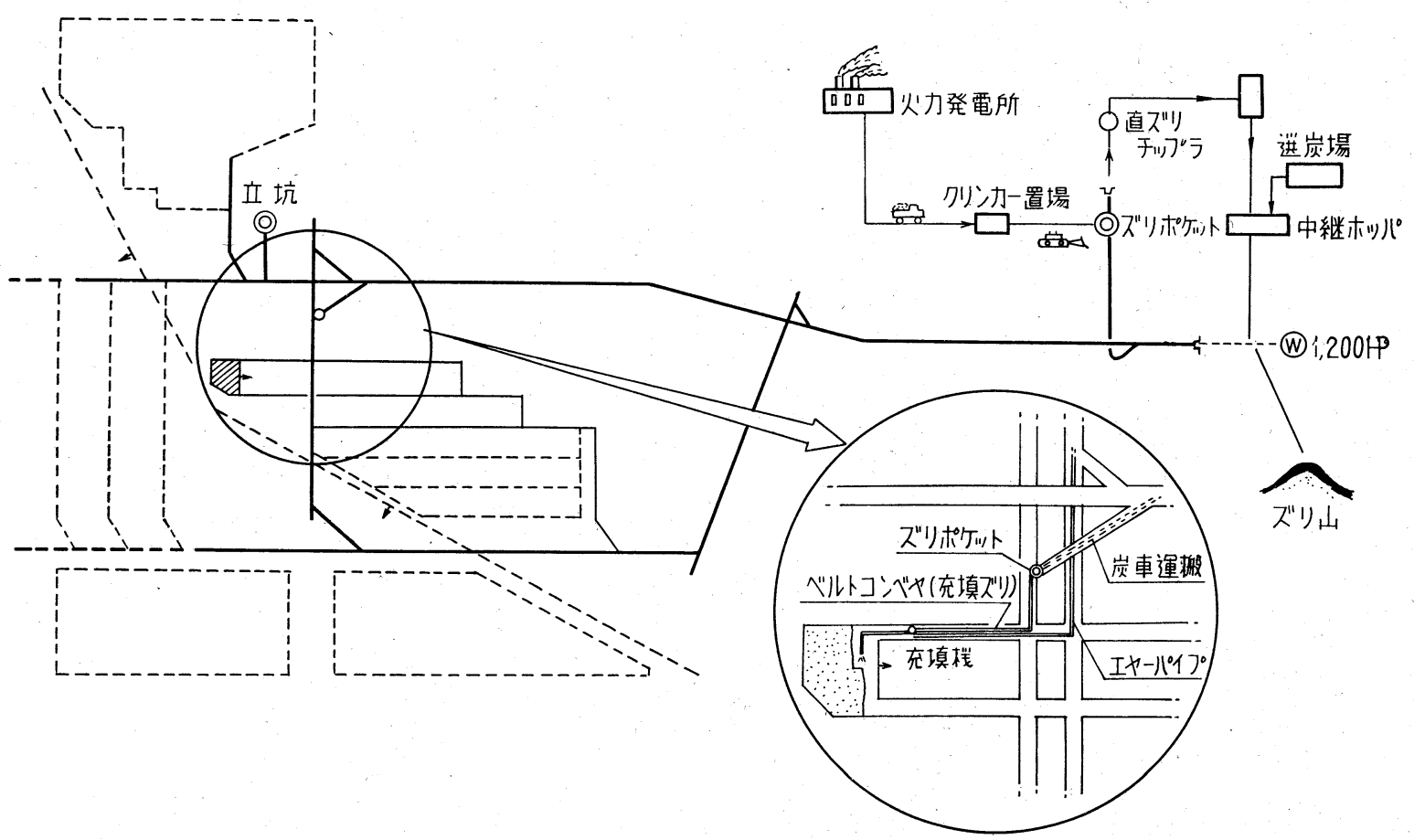

第 3 図一払の充填材搬入系統図

$396\langle 10\rangle$ 
填機に送り込まれる。一方, 充填用圧気は坑外に $670 \mathrm{~kW}$ $\times 157.5 \mathrm{~m}^{3} / \mathrm{min} \times 7 \mathrm{~kg} / \mathrm{cm}^{2}$ の、コンプレッサを新設し， 立坑経由圧気パイプから充塡機に結合される。圧気降下 を防ぐため主回路は $300 \mathrm{~mm}$ ，肩坑道は $200 \mathrm{~mm}$ のパイプ を使用した。充填パイプは $175 \mathrm{~mm} \phi \times 2 \mathrm{~m} /$ 本もので切羽 は K C P 管 $140 \mathrm{~m}$ 内外，片盤はニハード管 $40 \sim 80 \mathrm{~m}$ で

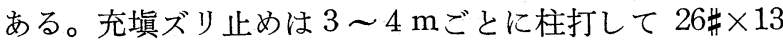
$\mathrm{mm} \times 1,600 \mathrm{~mm}$ の金網を張り切羽街道へのズリのなだれ 込みを防止し，カッペ 1.5 枚分すなわち $2.1 \mathrm{~m}$ ずつ下部 よりパイプを切断しつつ吹かし上がる。切断されたパイ プは新街道に配置されてクイックカップリングによつて 接続される。充填機は公称能力 $150 \mathrm{~m}^{3} / \mathrm{h}$ の Bein ST$150 \mathrm{~A}$ を使用した。

なお，充塡内にパイロメーターを埋設し充填内部の温 度変化を，また同様に差動トランスを利用した盤圧計お よび上下盤接近測定器を埋設し充塡内部の圧力変化, 上 下盤接近量の変化を定量的に測定した。

以上のような操業を西部五斜坑右 2 片さらに左 2 片で 41年12月までつづけた。

その効果について従来の総ばらし採炭と比較して列挙 すれば,つつぎのようである。

i ）総ばらし切羽では払進行約 $38 \mathrm{~m}$ で払跡内部は $70^{\circ} \mathrm{C}$ に達し（第 4 図），これが熱気となつて吹き出していた が，充继払では $115 \mathrm{~m}$ 奥部で約 $50^{\circ} \mathrm{C}$ となが熱気は完全 に遮断され切羽面に吹き出ないため第 5 図に示すように 深肩の温度差は総ばらし切羽で $12^{\circ} \mathrm{C}$ あたものが $4{ }^{\circ} \mathrm{C}$ 前 後となり大幅な温度低下となつた。

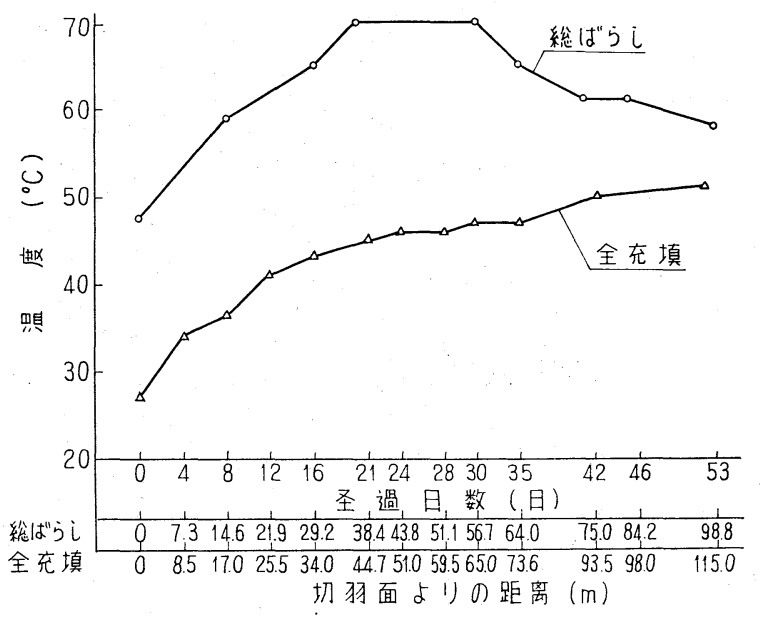

第 4 図 払跡温度の比較

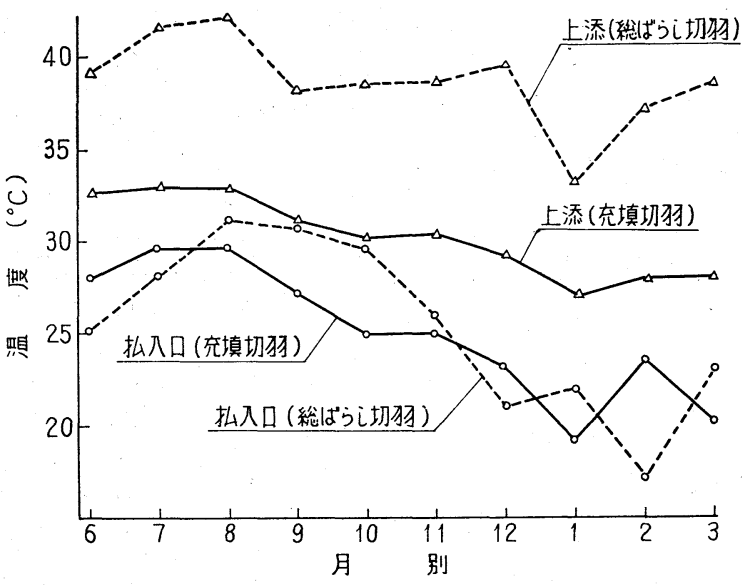

第 5 図 充填切羽と総ばらし切羽の温度対比

第 5 表 払能率, 出炭, 原価対比表

一昭41.9-

\begin{tabular}{|c|c|c|c|c|c|c|c|}
\hline & 東 & 部 & 磄 & & 部 & 磄 & \\
\hline & 鹿 & & 島 & 中 & 部 & 南 & 部 \\
\hline & 右二電右五片 & 右二電左五片 & 左二電左三片 & 四斜坑右四片 & 五斜坑右二片 & 右斜坑右二片 & $510 \mathrm{~m}$ 左四片 \\
\hline 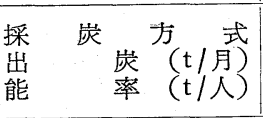 & $\begin{array}{c}\text { D.C 水圧鉄柱 } \\
14,300 \\
4.61\end{array}$ & $\begin{array}{c}\text { D.C自走枠 } \\
10,600 \\
5.76\end{array}$ & $\begin{array}{c}\text { 摩 擦 鉄 柱 } \\
6,300 \\
3.57\end{array}$ & $\begin{array}{c}\text { 水压鉄 柱 } \\
4,000 \\
5.46\end{array}$ & 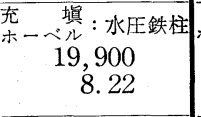 & $\begin{array}{c}\text { ホーベル, 水圧鉄柱 } \\
8,600 \\
3.95\end{array}$ & $\begin{array}{c}\text { ホーベル，自走枠 } \\
12,500 \\
5.39\end{array}$ \\
\hline 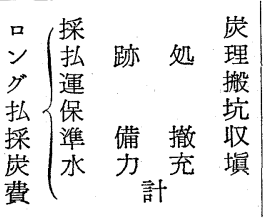 & $\begin{array}{c}732(\text { 円 } / \mathrm{t}) \\
81 \\
67 \\
161 \\
17 \\
\overline{-} \overline{58}\end{array}$ & $\begin{array}{r}583 \\
59 \\
73 \\
228 \\
12 \\
955\end{array}$ & $\begin{array}{r}668 \\
152 \\
40 \\
255 \\
18 \\
1,133\end{array}$ & $\begin{array}{r}467 \\
61 \\
7 \\
372 \\
130 \\
24 \\
1,061\end{array}$ & $\begin{array}{r}353 \\
10 \\
34 \\
96 \\
21 \\
\overline{514}\end{array}$ & $\begin{array}{r}865 \\
68 \\
29 \\
333 \\
71 \\
2 \\
1,368\end{array}$ & $\begin{array}{r}640 \\
13 \\
60 \\
270 \\
11 \\
16 \\
1,010\end{array}$ \\
\hline 鉄柱カッペ損耗 & 278 & 91 & 72 & 125 & 13 & 103 & 35 \\
\hline $\begin{array}{c}\text { 諸 } \\
\text { 経 } \\
\text { 筫 } \\
\text { 空 気 } \\
\text { 合 }\end{array}$ & $\begin{array}{r}\overline{-} \\
\overline{43} \\
1,379\end{array}$ & $\begin{array}{r}\frac{27}{36} \\
1,109\end{array}$ & $\frac{\overline{-}}{1,205}$ & $\overline{\bar{Z}}$ & $\begin{array}{r}\overline{269} \\
\overline{796}\end{array}$ & $\overline{-}$ & $\frac{8}{1,053}$ \\
\hline 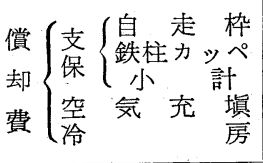 & $\begin{array}{l}\overline{44} \\
\overline{44} \\
\overline{18}\end{array}$ & $\begin{array}{r}129 \\
10 \\
139 \\
-15\end{array}$ & $\begin{array}{l}\overline{60} \\
60 \\
-\end{array}$ & $\begin{array}{l}\text { 79 } \\
79 \\
-\end{array}$ & $\begin{array}{r}- \\
51 \\
51 \\
147 \\
-\end{array}$ & $\begin{array}{l}\overline{114} \\
114 \\
-\end{array}$ & $\begin{array}{r}127 \\
27 \\
154 \\
- \\
-\end{array}$ \\
\hline 再 & 1,441 & 1,263 & 1,265 & 1,265 & 994 & 1,585 & 1,207 \\
\hline 備 & 総ばらし払 & $"$ & $"$ & " & 全充填 払 & 総ばらし払 & " \\
\hline
\end{tabular}


ii）充填材による天盤支持ができ，切羽 は重圧より解放され安定した出炭が可能と なつた。

iii）払跡への空気の流入がなくなり，酸 化作用は止まり自然発火のおそれは皆無と なつた。

iv）第 5 表に示すように出炭は上昇し, 能率も従来 $5 \mathrm{t} /$ 人程度であつたものが $8 \mathrm{t} /$ 人 台へと大幅に上昇し集約への足がかりが㨔 めた。

v）出炭増, 能率上昇によつて切羽原価 は 1,000 円 $/ \mathrm{t}$ を割つた。

\section{$3 \cdot 3$ 全払充填化}

前述のように一切羽充䁚の結果，その效 果にきわめて著しいものがあつたため, 当 所の合理化はまず全払を充塡することであ るといら方針を決定し，41年11月より工事に着手し，14 億円を投して 42 年 11 月に一切の設備を完成， 4 切羽充塡 払の操業に入つた。

主なる設備内容はつぎのようである。

i ）充填用コンプレッサとして東部矿は $720 \mathrm{~kW} 3$ 台 新設，西部砿は 3 台を増設し 4 台とした。

ii）圧気パイプは人車立坑のバントンの強度の点か ら，新たに給気ボーリングを開発し東部砿は $16 \mathrm{in} ，$ 西部 砿は $12 \mathrm{in}$ パイプをそれぞれ挿入した。

iii）充塡機は Beien ST-150A では充填能率が $80 \mathrm{~m}^{3} / \mathrm{h}$ 内外で，したがつて出炭は $30,000 \mathrm{t} /$ 月 内外に抑えられ るので Brieden KZ-250 型とし，充填パイプも $175 \mathrm{~mm}$ から $225 \mathrm{~mm}$ として 40,000 50,000t/月の出炭に対応 できるようにした。

iv）掘進ズリの破砕は東部砇は坑外で，西部砇は西部 斜坑の運搬能力の点から坑内で行ならべくそれぞれクラ ッシヤ設備を設けた。

v）ズリ山取り崩しとしてブルドーザをズリ山に張り 付け，ダンプトラックでクラッシヤプラントまで運搬 し，これよりベルトで坑ロズリポケットに搬入する一連 のズリ山設備を設けた。

以上のような設備を以つて東西各 2 払の充塤払の操業 を開始, 第 6 表に示すように故障時間も遂次減少し, 充
第 6 表 充塡量, 能率, 故障時間推移表

\begin{tabular}{c|c|c|c|c|c}
\multicolumn{2}{c|}{41} & 年 & \multicolumn{2}{|c|}{42 年 } & \multicolumn{2}{|c}{43 年 } \\
\hline 上 & 下 & 上 & 下 & 上 & 下 \\
\hline
\end{tabular}

\begin{tabular}{ll|l|l|l}
- & $-29,468$ & 140,036 & 160,563 & 219,934 \\
\hline
\end{tabular}

\begin{tabular}{lll|l|l|l|l}
44,923 & 83,468 & 80,478 & 195,933 & 224,619 & 263,766
\end{tabular} \begin{tabular}{l|l|l|l|l|l|l|}
44,923 & 83,468 & 109,946 & 335,969 & 385,182 & 483,700
\end{tabular}

\begin{tabular}{l|l|l|l|l|l}
18,179 & 23,230 & 53,437 & 158,348 & 116,356 & 113,019 \\
\hline
\end{tabular}

\begin{tabular}{l|l|l|l|l|l|l}
12,092 & 25,206 & 22,268 & 105,247 & 140,843 & 199,742
\end{tabular}

$\begin{array}{lllllll}14,646 & 25,109 & 23,403 & 10,364 & 15,846 & 24,480\end{array}$ \begin{tabular}{r|r|r|r|r|r|}
0 & 8,923 & 10,838 & 62,010 & 112,143 & 146,459 \\
\hline
\end{tabular}

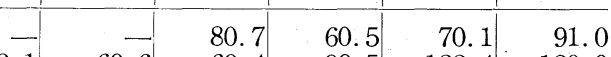

\begin{tabular}{r|r|r|r|r|r}
\hline 3.1 & 69.6 & 69.4 & 99.5 & 122.4 & 120.0
\end{tabular}

\begin{tabular}{l|r|r|r|r|r}
53.1 & 69.6 & 75.1 & 80.0 & 96.3 & 106.0 \\
\hline
\end{tabular}

\begin{tabular}{l|l|l|l|l|l}
- & - & 0.77 & 0.64 & 0.65 & 0.68
\end{tabular}

\begin{tabular}{lllllll}
\hline 73 & 0.62 & 0.61 & 0.57 & 0.62 & 0.66 \\
\hline
\end{tabular}

\begin{tabular}{ll|l|l|l|l|}
0.73 & 0.62 & 0.68 & 0.61 & 0.64 & 0.67 \\
\hline
\end{tabular}

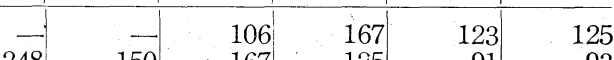

\begin{tabular}{r|r|r|r|r|r}
248 & 150 & 137 & 141 & 107 & 109 \\
\hline
\end{tabular}

填能率も $120 \mathrm{~m}^{3} / \mathrm{h}$ まで上昇してきた。

$10 \mathrm{~mm}$ 以下の劣悪な材料も使用して $3,000 \sim 3,500 \mathrm{~m}^{3} /$ 日に及ぶ大規模な充填を成し遂げ当所の致命的な自然条 件を克服して切羽重装備, 集約合理化の基盤をつくつ た。一方, 開坑以来つづけていたズリ山へのズリ捨ては 皆無となり, 逆にズリ山を取り崩して坑内に還元してい るためズリ山の様相は一変しつつある。

\section{4. 切羽の重装備と集約}

切羽の環境が大幅に改善されたので, 単位切羽よりの 出炭量増大のためのつぎの段階はまず発破作業を無くす ことである。発破作業が続行する限りそのために要する 退避時間のロス, 大塊発生によるコンベヤの停止, 故障, 飛散炭のショベリング等は免れず大幅な能率上昇は期待 できない。

そこで三作製 $150 \mathrm{~kW}$ シングルレンジングドラムカッ タを東部砝で 42 年 3 月より 10 月まで試験操業を行なつ た。その結果, 切截能力その他に自信を得たのでつづ て42年 11 月 $200 \mathrm{~kW}$ ダブルレンジングドラムカッタ (D RDC) を導入，相ついで No. $2 \sim$ No. 5 を入れ，現在 4 切羽に稼働している。DRDC の導入に゙より切羽は全 面切截が可能となり，発破はステーブルを除いて皆無と なり，また切截後の残炭も Loading Wedge を使用し

第 7 表 代表払の出炭および能率の比較

\begin{tabular}{|c|c|c|c|c|c|c|c|c|}
\hline & 10 月 & 11 月 & 12 月 & 1 月 & 2 月 & 3 月 & 6 力月平均 & $\begin{array}{l}\text { 総ばらし } \\
\text { 十ホーベルを } \\
100 \text { とした場合 }\end{array}$ \\
\hline $\begin{array}{l}510 \mathrm{~m} \text { 左 } 3 \text { 片,左 } 4 \text { 片 } \\
\text { (総ばらしナホーベル) }\end{array}$ & $\begin{array}{r}12,100 \mathrm{t} / \text { 月 } \\
4.93 \mathrm{t} / \text { 人 }\end{array}$ & $\begin{array}{r}14,800 \\
5.74\end{array}$ & $\begin{array}{r}11,500 \\
4.82\end{array}$ & $\begin{array}{r}15,500 \\
6.43\end{array}$ & $\begin{array}{r}18,200 \\
6.96\end{array}$ & $\begin{array}{r}20,000 \\
7.04\end{array}$ & $\begin{array}{r}15,400 \\
6.03\end{array}$ & $\begin{array}{l}100 \\
100\end{array}$ \\
\hline $\begin{array}{c}\text { 五 斜 坑 左 } 3 . \text { 片 } \\
\text { (充填十ホーベル) }\end{array}$ & $\begin{array}{r}16,300 \\
5.96\end{array}$ & $\begin{array}{r}25,100 \\
8.10 \\
\end{array}$ & $\begin{array}{r}23,000 \\
7.06 \\
\end{array}$ & $\begin{array}{r}25,000 \\
8.14\end{array}$ & $\begin{array}{r}31,000 \\
9.21\end{array}$ & $\begin{array}{r}30,500 \\
10.16\end{array}$ & $\begin{array}{r}25,200 \\
8.19\end{array}$ & $\begin{array}{l}163.6 \\
135.8\end{array}$ \\
\hline $\begin{array}{c}\text { 五斜坑左 } 4 \text { 片左 } 5 \text { 片 } \\
(\text { 充填 +DRDC) }\end{array}$ & $\begin{array}{r}43,500 \\
13.57\end{array}$ & $\begin{array}{r}34,100 \\
10.4\end{array}$ & $\begin{array}{r}33,000 \\
11.28\end{array}$ & $\begin{array}{r}38,000 \\
12.73\end{array}$ & $\begin{array}{r}39,100 \\
13.26\end{array}$ & $\begin{array}{r}50,500 \\
14.76\end{array}$ & $\begin{array}{r}39,700 \\
12.71\end{array}$ & $\begin{array}{l}257.8 \\
210.8\end{array}$ \\
\hline
\end{tabular}

$398\langle 12\rangle$ 
第 8 表 切羽集約推移表

\begin{tabular}{|c|c|c|c|c|c|c|c|c|}
\hline & \multicolumn{2}{|c|}{ 41年 } & \multicolumn{2}{|c|}{ 42年 } & \multicolumn{2}{|c|}{ 43年 } \\
\hline & & & 上 & 下 & 上 & 下 & 上 & 下 \\
\hline \multirow{3}{*}{$\begin{array}{l}\text { 口 } \\
\text { Y } \\
\text { グ } \\
\text { 平 } \\
\text { 均 } \\
\text { 数 }\end{array}$} & 東部砄 & $\begin{array}{l}\text { 湯本 } \\
\text { 鹿島 }\end{array}$ & $\begin{array}{l}1 \\
3\end{array}$ & $\begin{array}{l}2 \\
3 \\
\end{array}$ & $\begin{array}{l}1 \\
3\end{array}$ & $\begin{array}{l}0 \\
2\end{array}$ & $\begin{array}{l}0 \\
2\end{array}$ & $\begin{array}{l}0 \\
2\end{array}$ \\
\hline & 西部矿 & $\begin{array}{l}\text { 中部 } \\
\text { 南部 }\end{array}$ & $\begin{array}{l}2 \\
2\end{array}$ & $\begin{array}{l}1 \\
2\end{array}$ & $\begin{array}{l}1 \\
2\end{array}$ & $\begin{array}{l}3 \\
0\end{array}$ & $\begin{array}{l}2 \\
0\end{array}$ & 2 \\
\hline & \multicolumn{2}{|c|}{ 計 } & 8 & 8 & 7 & 5 & 4 & 4 \\
\hline 総 & 面 長 & (m) & 962 & 872 & 825 & 732 & 623 & 688 \\
\hline \multicolumn{3}{|c|}{$\begin{array}{l}\text { 全出炭に対す } \\
\text { るロソグ比率(\%) }\end{array}$} & 65.6 & 66.0 & 73.5 & 74.1 & 75.7 & 75.8 \\
\hline
\end{tabular}

$3 \mathrm{~m}$ ごとに取付けられた $10 \mathrm{t}$ Shifter によつて 押入積 込みされるためショベリングはほとんどなくなつた。肩 梁は Anchorage で駆動トラフを固定し，ケーブルは Handler で操作される。このような 重装備化によつて 単位切羽当りの出炭は飛躍的に上昇し, 精炭 35,000 $40,000 \mathrm{t} /$ 月の出炭が可能となつた。

従来の代表的な総ばらし十ホーベルと充填 + ホーベ ル, 充塡 $+\mathrm{DRDC}$ 切羽について比較すれば第 7 表のよう で総ばらし十ホーベルに比し充继 $+\mathrm{DRDC}$ は平均で出 炭が2.6倍, 能率は2.1倍となり本年 3 月には遂に $50,000 \mathrm{t} /$ 月（原炭70,000t/月）の出炭をみるに至りまさに様相の 変わつた切羽が誕生するに至つた。このような単位切羽 当り出炭量の増大によつて第 8 表に示すように東部砿の 湯本方部, 西部吰の南部方部を採掘中止し従来 4 方部 8 切羽であつたものを 2 方部 4 切羽へと集約した。

\section{5. 冷房}

前述のように払跡の全充塡によつて温度上昇の原因と なる熱気を完全に遮断することにより, 冬季は入気立坑 の効果をフルに受けるが，夏季にあつては入気そのもの の温度が高いため深坑道ですでに $30^{\circ} \mathrm{Cに}$ 達するので払上

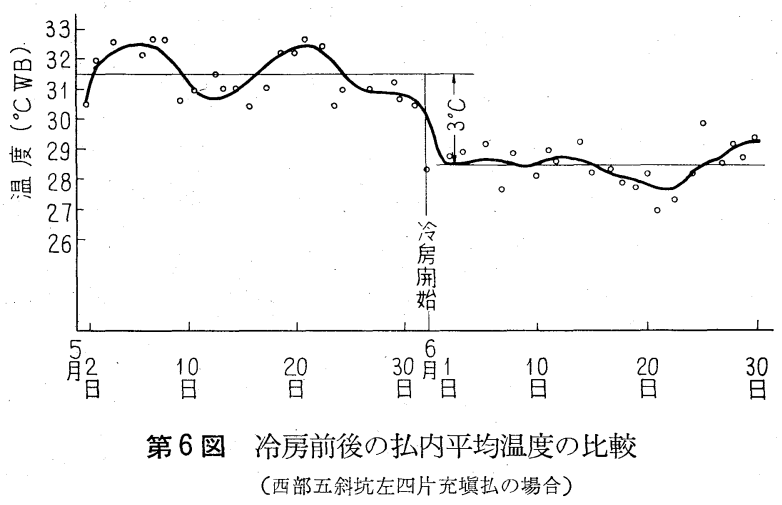

部では $35^{\circ} \mathrm{C}$ となる。この対策としては入気温度を下げ る冷房以外にはない。

そこで払は夏季といえども平均 $29^{\circ} \mathrm{CW} . \mathrm{B}$ 以下を目標 に $120 \mathrm{R} \mathrm{T}$ ，掘進は $27^{\circ} \mathrm{CW}$. B 以下を目標に $40 \mathrm{R} \mathrm{T}$ を以 つて冷房することにした。

東部矿は $500 \mathrm{R} \mathrm{T}$ ，西部矿は $630 \mathrm{R}$ T プラントをそれ ぞれ坑外に設置し, 飲料水を $5{ }^{\circ} \mathrm{C}$ 程度まで下げ，スチロ ールフォームで保冷されたパイプを通じ切羽のクーラー に送り熱交換させる。

第 6 図は払における実績の一例で約 $3^{\circ} \mathrm{C}$ W. B の低下 となり夏季といえども春秋の環境を再現させることがで きた。

\section{6. 総 合 効 果}

以上のように充塡を基盤として切羽の重装備化, 集約, 冷房によつて合理化は急速に進み，第 9 表に示すように 合理化前の 40 年に比し, 出炭は従来 1 切羽平均 $12,000 \mathrm{t} /$ 月, 最高ですら $18,000 \mathrm{t} /$ 月 程度であつたものが平均で $29,000 \mathrm{t} /$ 月, 最高は $50,000 \mathrm{t} /$ 月を超すに至り, 能率も $5 \mathrm{t} /$ 人台から $10 \mathrm{t} /$ 人 へと飛躍した。したがつて切羽数 は半減したにもかかわらす総出炭は増加し，在籍人員は 5,000 名加ら 4,000 名となり, 全在籍能率も $30 \mathrm{t} /$ 人・月台

第 9 表 出炭と在籍および能率の比較

\begin{tabular}{|c|c|c|c|c|c|c|c|c|c|c|}
\hline & 10 月 & 11 月 & 12 月 & 1 月 & 2 月 & 3 月 & 6 力月平均 & $\begin{array}{l}\text { 合理化前を } \\
100 \text { とした } \\
\text { 場合 }\end{array}$ \\
\hline \multirow{3}{*}{$\begin{array}{c}\text { 合 } \\
\text { 理 } \\
\text { 化 } \\
\text { 前 } \\
\text { (40年) }\end{array}$} & \multicolumn{2}{|c|}{ 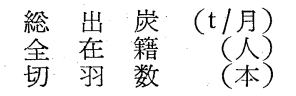 } & $\begin{array}{r}150,000 \\
4,915 \\
8.0\end{array}$ & $\begin{array}{r}165,000 \\
5,008 \\
8.0\end{array}$ & $\begin{array}{r}163,000 \\
5,068 \\
8.1\end{array}$ & $\begin{array}{r}162,000 \\
5,046 \\
8.0\end{array}$ & $\begin{array}{r}142,100 \\
5,040 \\
8.0\end{array}$ & $\begin{array}{r}155,500 \\
5,019 \\
7.7\end{array}$ & $\begin{array}{r}156,300 \\
5,016 \\
8.0\end{array}$ & $\begin{array}{l}100 \\
100 \\
100\end{array}$ \\
\hline & 払出炭 & $\begin{array}{ll}\text { 平 均 }(\mathrm{t} / \text { 月 }) \\
\text { 最 高 }(=)\end{array}$ & $\begin{array}{l}11,800 \\
13,700\end{array}$ & $\begin{array}{l}12,800 \\
15,800\end{array}$ & $\begin{array}{l}12,500 \\
17,200\end{array}$ & $\begin{array}{l}12,900 \\
17,700\end{array}$ & $\begin{array}{l}11,800 \\
15,500\end{array}$ & $\begin{array}{l}12,700 \\
15,500\end{array}$ & $\begin{array}{l}12,400 \\
15,900\end{array}$ & $\begin{array}{l}100 \\
100\end{array}$ \\
\hline & 能 率 & $\begin{array}{l}\text { 払 }(t / 人) \\
\text { 全在籍 (") }\end{array}$ & $\begin{array}{r}5.2 \\
30.5\end{array}$ & $\begin{array}{r}5.6 \\
32.9\end{array}$ & $\begin{array}{r}5.6 \\
32.2\end{array}$ & $\begin{array}{r}6.0 \\
32.1\end{array}$ & $\begin{array}{r}5.9 \\
28.2\end{array}$ & $\begin{array}{r}5.6 \\
31.0\end{array}$ & $\begin{array}{r}5.6 \\
31.2\end{array}$ & $\begin{array}{l}100 \\
100\end{array}$ \\
\hline $\begin{array}{l}\text { 合 } \\
\text { 理 }\end{array}$ & $\begin{array}{l}\text { 総 出 } \\
\text { 全 在 } \\
\text { 切 羽 }\end{array}$ & $\begin{array}{c}\text { 炭 } \\
\text { 籍 } \\
\text { 数 } \\
\text { 作 }) \\
\text { (本) }\end{array}$ & $\begin{array}{r}158,500 \\
4,098 \\
4.0\end{array}$ & $\begin{array}{r}143,500 \\
4,125 \\
4.0\end{array}$ & $\begin{array}{r}154,500 \\
4,115 \\
4.0\end{array}$ & $\begin{array}{r}166,000 \\
4,107 \\
4.0\end{array}$ & $\begin{array}{r}157,800 \\
4,073 \\
4.0\end{array}$ & $\begin{array}{r}180,000 \\
4,053 \\
4.0\end{array}$ & $\begin{array}{r}160,100 \\
4,095 \\
4.0\end{array}$ & $\begin{array}{r}102.4 \\
81.8 \\
50.0\end{array}$ \\
\hline 化 & 払出炭 & $\begin{array}{ll}\text { 平 均 }(\mathrm{t} / \text { 月 }) \\
\text { 最 } \\
\text { 高 (" })\end{array}$ & $\begin{array}{l}30,300 \\
43,500\end{array}$ & $\begin{array}{l}27,000 \\
32,500\end{array}$ & $\begin{array}{l}25,100 \\
33,000\end{array}$ & $\begin{array}{l}28,500 \\
38,000\end{array}$ & $\begin{array}{l}28,500 \\
39,100\end{array}$ & $\begin{array}{l}32,600 \\
50,500\end{array}$ & $\begin{array}{l}28,700 \\
39,400\end{array}$ & $\begin{array}{l}231.5 \\
247.8\end{array}$ \\
\hline (43年) & 能 率 & $\begin{array}{l}\text { 払 }(t / 人) \\
\text { 全在籍 }(")\end{array}$ & $\begin{array}{r}10.32 \\
38.7\end{array}$ & $\begin{array}{l}9.42 \\
34.8\end{array}$ & $\begin{array}{l}9.01 \\
37.5\end{array}$ & $\begin{array}{r}10.23 \\
40.4\end{array}$ & $\begin{array}{r}10.78 \\
38.7\end{array}$ & $\begin{array}{r}11.35 \\
44.4\end{array}$ & $\begin{array}{l}10.2 \\
39.1\end{array}$ & $\begin{array}{l}182.1 \\
125.3\end{array}$ \\
\hline
\end{tabular}


で低迷していたものがきわめて不利な自然条件下の採掘 にもかかわらずようやくにして $40 \mathrm{t} /$ 人月となつた。 なお，切羽の若返りによつて従来地熱のためせいぜい -900m ラインが採掘の限界とされていた東部矿もこの 施策によつて $-1,300 \mathrm{~m}$ 程度までは充分採掘できる確信 を得た。また地上物件と競合する西部矿も充填によつて 地上への影響が緩和されるので，当然実収炭量の増加が 見込める等, 地下資源の有効利用の面からも多大の効果 がある。

\section{7. あとがき}

現在までに 2 方部， 4 切羽，年間 180 万 $\mathrm{t}$ 出炭の態勢 が完成したが，さらに年産 200 万 $\mathrm{t}$ に飛躍し，めわせて 労務者の減少，老令化の対策として切羽の機械化，無人 化を推進し，また切羽の大型化の反面，断層閒炭柱の高 能率採炭を計るなどなお多くの問題を解決しなければな らない。

そこで今後の合理化の主なるものとしては

i ）払内作業の $39 \%$ を占める立柱, 抜柱の作業を自走
化によつて軽減し高能率化に結びつける。

ii） $36 \%$ を占める充塡作業を充填壁の工夫等により高 能率化を計る。

iii）ステーブルの機械化あるいはノンステーブル化を 進める。

iv）断層間の小残存炭柱を機械化によつて効率良く採 掘する。

v）保有炭量確保，炭層状況の把握のため掘進の機械 化により急速掘進のレベルを上げる。

vi）坑内外にわたる自動化，機械化を進め省力化を計 る。

以上当砿の合理化の実態と今後の考え方を述べたが生 産, 保安, 労務あらゆる面で一日たりとも停滞の許され ない厳しい炭界にあつてこの報告がいささかなりとも参 考になれば幸甚の至りである。

なおこれらの成果は社内外の上司先輩各位の懇切なる ご指導と，額に汗して努力を惜しまなかつた矿業所現場 諸君のご協力によるもので，この機会に心から御礼申し 上げる次第である。

\title{
Improvement of Working Surroundings and Integrated Rationalization by Means of Full Stowing in Iwaki Coal Mine
}

\author{
by Motoharu OKABE
}

The water dranage of the mine amounts to $144 \mathrm{~m}^{3} / \mathrm{min}$, and $120 \mathrm{~m}^{3} / \mathrm{min}$ of which has a temperature of around $70^{\circ} \mathrm{C}$. The geothermal gradient of the mine is $10 \sim 15 \mathrm{~m} /{ }^{\circ} \mathrm{C}$ and the underground environment is so bad that the rock temperature of the present working areas amounts to about $60^{\circ} \mathrm{C}$. In order to overcome this unfavourable condition the following counterplans have been carried out with good results.

Since 1967 the pneumatic stowing apparatus have been equipped with the investment corresponding to U. S. T4.5 mill. for the full stowing into all the gobs. The full stowing of gob and the cooling of working face by the powerful refrigerators have been able to lower the temperature difference between the entrance and the end of each working place from $12 \mathrm{deg}$. to $4 \mathrm{deg}$. in centigrade and have succeeded in the improvement of working surroundings. The amount of daily stowing is about 3,000 to $3,500 \mathrm{~m}^{3}$. The longwalls have been fully mechanized with $200 \mathrm{~kW}$ double ranging drum sherers.

As the result of these improvements, the coal output of a unit face, face efficiency and overall efficiency have rised from 12,000 14,000 t/month, $5 \mathrm{t} / \mathrm{man} / \mathrm{sh}$ ift and $26 \sim 28 \mathrm{t} / \mathrm{man} / \mathrm{month}$ in 1966 to 35,000 40,000 t/month, 10t/ $\mathrm{man} / \mathrm{shift}$ and $40 \mathrm{t} / \mathrm{man} / \mathrm{month}$ respectively. The possibility of deep mining has been fixed by the full stowing in all the gobs and the proved coal reserve has increased in proportion to the fact. The organization for 1.8 mill. ton of output in 1969 has been established and it will be possible in the near future to output 2 mill. ton or more per year. 